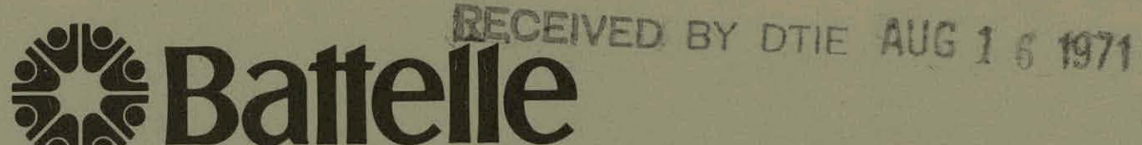

Pacific Northwest Laboratories

Richland, Washington 99352

THIS DOCUMENT CONFIRMED AS UNCLASSIFIED

DIVISION OF CLASSIFICATION

BY

DATE

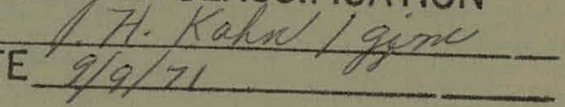

This report is intended primarily for internal use by the sponsoring organization and Battelle.

SUMMARY REPORT ON ANALYSIS
OF THE SEMI -FLUID CONDITION IN THE PG -6
PHOSPHATE GLASS SOLIDS CONTAINER
MAY 1971

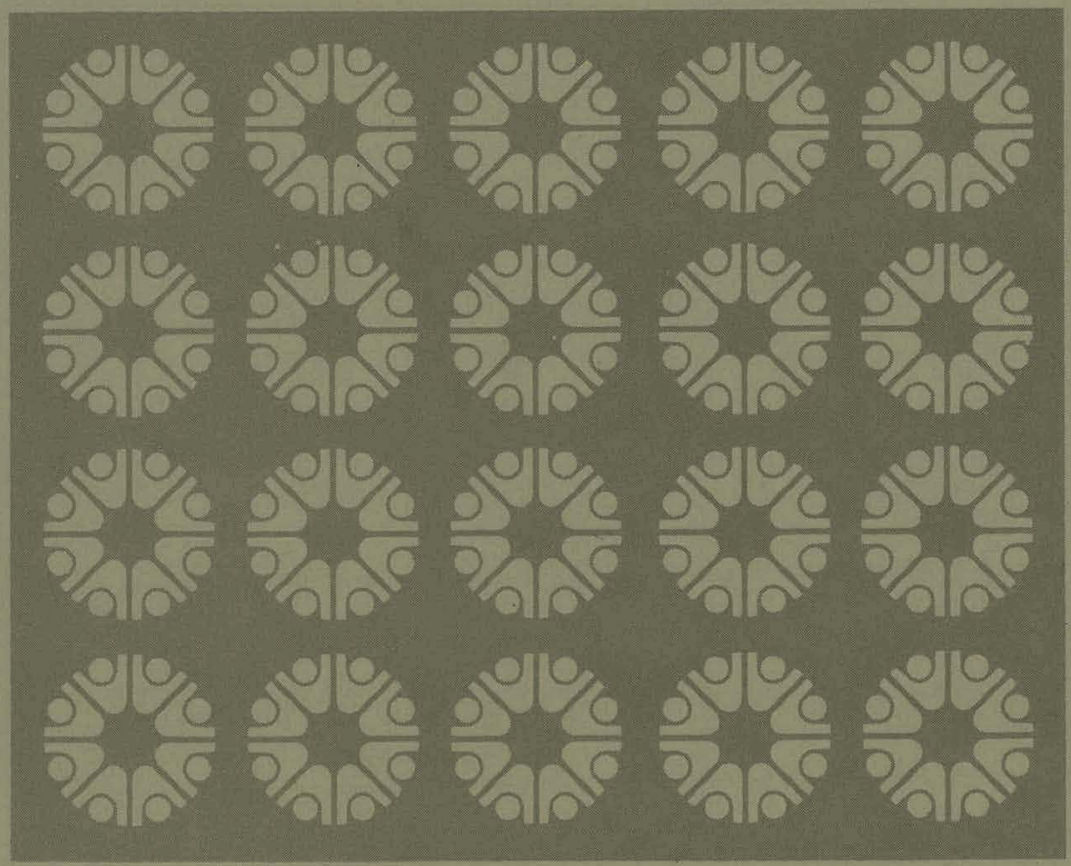




\section{DISCLAIMER}

This report was prepared as an account of work sponsored by an agency of the United States Government. Neither the United States Government nor any agency Thereof, nor any of their employees, makes any warranty, express or implied, or assumes any legal liability or responsibility for the accuracy, completeness, or usefulness of any information, apparatus, product, or process disclosed, or represents that its use would not infringe privately owned rights. Reference herein to any specific commercial product, process, or service by trade name, trademark, manufacturer, or otherwise does not necessarily constitute or imply its endorsement, recommendation, or favoring by the United States Government or any agency thereof. The views and opinions of authors expressed herein do not necessarily state or reflect those of the United States Government or any agency thereof. 


\section{DISCLAIMER}

Portions of this document may be illegible in electronic image products. Images are produced from the best available original document. 


\section{NOTICE}

This report was prepared as an account of work sponsored by the United States Government. Neither the United States nor the United States Atomic Energy Commission, nor any of their employees, makes any warranty, express or implied, or assumes any legal liability or responsibility for the accuracy, completeness or usefulness of any information, apparatus, product, or process disclosed, or represents that its use would not infringe privately-owned rights.

PACIFIC NORTHWEST LABORATORY

operated by

BATTELLE MEMORIAL INSTITUTE

for the

U. S. ATOMIC ENERGY COMMISSION

Under Contract AT(45-1) 1830 


\title{
SUMMARY REPORT ON ANALYSIS OF THE \\ SEMI-FLUID CONDITION IN THE PG-6 \\ PHOSPHATE GLASS SOLIDS CONTAINER.
}

\section{by}

\author{
J. L. McElroy, \\ J. E. Mendel, \\ and
}

F. P. Roberts This report was prepared as an account of work
sponsored by the United States Government. Neither
the. United States nor the United States Atomic Energy
Commission, nor any of their employees, nor any of
their contractors, subcontracturs, or their employees,
makes any warranty, express or implied, or assumes any
legal liability or responsibility for the accuracy, com-
pleteness or usefulness of any information, apparatus,
product or process disclosed, or represents that its use
would not infringe privately owned rights.

May 1971 
THIS PAGE

\section{WAS INTENTIONALLY LEFT BLANK}




\section{CONTENTS}

\begin{tabular}{|c|c|c|c|c|c|}
\hline INTRODUCTION • & • & • & - & • & - 1 \\
\hline SUMMARY AND CONCLUSIONS & - & $\cdot$ & - & $\bullet$ & 2 \\
\hline PHOSPHATE GLASS POT PG- 6 & HISTORY & • & 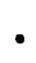 & $\bullet$ & 6 \\
\hline SIGNIFICANT FINDINGS & - & • & • & • & 16 \\
\hline
\end{tabular}




\section{FIGURES}

1. PG-6 Pot Temperature History Il

2 Upper and Middle Core Drill Holes 14

Upper Core Drill Hole
on PG-6 Pot

4 PG-6 Pot In Environmental Storage 17

\section{TABLES}

I Phosphate Glass Run PG-6 Pot History 7

II Corrosion Rates of Storage Vessels 18

III Laboratory Analysis of PG-6 Core Hole and Core Drill Samples

21

IV Leak Check Summary of all Phosphate Glass Pots 27 


\section{SUMMARY REPORT ON ANALYSIS OF THE \\ SEMI-FLUID CONDITION IN THE PG-6 \\ PHOSPHATE GLASS SOLIDS CONTAINER}

by

$$
\begin{aligned}
& \text { J. L. McElroy, } \\
& \text { J. E. Mendel, } \\
& \text { and } \\
& \text { F. P. Roberts }
\end{aligned}
$$

\section{INTRODUCTION}

During Phosphate Glass Run PG-6, in May 1968, an 8-inch stainless steel pot was successfully filled with phosphate glass. The pot was placed in interim water storage in B-Cell immediately after the run and in October 1969 the pot was transferred from B-Cell where the solidification test was performed to A-Cell where it was placed in a controlled water environment in the Solids storage Engineering Test Facility (SSETF). The pot was removed from the water environment in January 1969 for core drilling to obtain samples of the 32 month old product. When the pot was core drilled a thick semi-fluid material ran out of the top core drill hole and down the side of the pot where it solidified.

In the top core drill hole (zone 1) a semi-fluid region was located within the center of the pot. A second core drill near the pot mid-plane (zone 3) revealed only a slight amount of fluid present and a core drill near the bottom of the product (zone 6) revealed no fluid present.

In view of these unexpected phenomena and their potential importance, an extensive investigation of this incident was 
initiated to determine both the cause and the significance of the situation. This report summarizes the results of the investigation.

SUMMARY AND CONCLUSIONS

Failure of the pot thermocouple well allowed water to enter the PG-6 pot while it was in water storage in an environmental test pod. The water entered the pot through the thermowell opening near the top of the pot probably from a combination of overfilling the storage water above the thermowell opening and from condensation in the top of the environmental pod. The investigation also established that the glass product was highly devitrified and that the water which entered the pot underwent a continuous boiling-refluxing action. The boiling refluxing resulted from the water contacting the hot product (the centerline temperature was $190^{\circ} \mathrm{C}$ at the start of the environmental test and $125^{\circ} \mathrm{C}$ at the conclusion of the test) and the condensation of the rising steam on the upper cooler surfaces of the pot; the condensed vapors then ran back into the product.

Previous accelerated (boiling water) leaching tests and tests which were conducted as a part of this investigation to simulate the leaching in the FG- 6 pot, demonstrated that severe leaching will occur under conditions involving boiling water and wherein the glass product has become devitrified. When 45 to 60 mesh solid grains are used as high as 50 wt: of the solid can be leached away in 72 hours if the product is highly devitrified.

In overall summary, the investigation has determined that the peculiar problem and happenings with the PG- 6 pot resulted from the following factors and events: (1) the 
phosphate glass was quite highly devitrified (particularly in the center core area); (2) the thermocouple wells failed after the unit had been placed in the environmental test; (3) water from the storage pod entered through the failed thermowells; and (4) a boiling-refluxing action occurred within the pot which severely leached and degraded a portion of the product.*

Other highlights and observations which resulted from the investigation are summarized in the remaindex of this section.

The pot temperature history for the PG-6 pot was such that corrosive failure of the thermowells would not have been anticipated. Except for the maximum temperature of $900^{\circ} \mathrm{C}$ that occurred during pot filling the pot internal temperatures were maintained below approximately $400^{\circ} \mathrm{C}$ by having the po't in water storage: Leak check data have established

*The finding that the phosphate glass product in the WSEP pots has devitrified completely is significant since it is well established that devitified phosphate glass leaches at a much higher rate than nondevitrified phosphate glass. $(1,2)$ However, even nondevitrified phosphate glass would be attacked at a signifi-: cant rate under the severe conditions of contact by boiling water or steam following in-leakage into the storage vessel (See page 2.5):

(1) R. J. Thompson, J."E. Mendel, J. H. Kleinpeter, Waste Solidification Demonstration Program: Characterization of Nonradioactive Samples of Solidified High-tevel Waște, p. 6.3, Table 6.1, BNWL-1393, June 1970 .

(2) A, G. Blasewitz, editor. Quarterly. Progress Report, Research and Development Activities, Fixation of Radioactive Residues, August, September and October, 1969. pp: 29-32. December, 1969: 
that the failure of the thermowells occurred while the pot was in the water environmental test pod with the waste solids temperature between 125 and $190^{\circ} \mathrm{C}$. (A thermowell failure is also known to have occurred in the PG-7 phosphate glass pot several months after the PG-7 run and 10 months after a leak test had shown the pot to be intact.) Possible explanations for the corrosive failure of the thermowells are being evaluated. A sticky acidic substance has sometimes been found on the surface of devitrified phosphate glass samples and the possibility of this material causing the corrosion is being pursued. It may also be possible that activation corrosion is being initiated during the pot high temperature history during pot filling, and that corrosion continues because deactivation does not occur during pot cool down.

It is believed that production pots will eventually not require thermocouples and hence no thermowells will be in the pots. If thermowells are required, however, then a new technique is required for locating the thermowells in the pot when phosphate glass is being produced.

No corrosion occurred to the pot walls. A wall thickness scan revealed a fairly uniform wall thickness with readings ranging from 0.313 to 0.352 inches (standard wall thickness is 0.322 inches).

Continuous monitoring of the PG-6 pot pressure during environmental storage indicated no pressurization during the breeching by water. This can be attributed to condensation of vapors (refluxing) in the top of the pot. 
A significant amount of radioactivity was not detected in the environmental storage water however, the thermowell openings were normally above the surface of the water so that flow between the pot and water could not occur.

The occurrence with the PG- 6 pot represents a credible accident, i.e., the breeching of a container of solidified waste stored under water. Consequently this circumstance should be analyzed for the parameters which exist for each specific situation (such as the product temperature, leachability and free space in the container). The occurrence also illustrates that adequate safeguards (such as requiring a leak test) must be taken before shipping containers of waste wherein water storage is a factor.

Core drill samples from the top, middle, and bottom of the pot show the product to be devitrified and to have a fairly uniform fission product distribution; only cesium was preferrentially leached and was predominant in the semi-fluid region. The semi-fluid material in the top core drill hole had a water content of $15 \mathrm{wt}$ \% while scrapings from the middle hole were only 4 wto water. The product in the bottom hole appeared chalky and crumbly and although it appeared dry $(<0.1$ wto water) it also appeared to have been wet at some time.

Additional phosphate glass pots will be leak checked or rechecked, including PG-5 pot, to determine the extent of the thermowell problem.

Phosphate glass pots will receive additional wall thickness measurements to assure that wall corrosion is not a problem. To date no wall corrosion has been observed. 
At least one thermally and radioactively "cold" phosphate glass pot will be core drilled to determine if it is possible to make and store a nondevitrified phosphate glass.

Additional core drills will be taken from the PG- 6 pot to obtain samples of the failed thermowells to assess the extent and nature of the corrosion.

Leach testing, simulating the PG- 6 incident, will be performed with other types of WSEP solid products to determine what would happen if one of these type containers were breeched by water.

PHOSPHATE GLASS POT PG-6 HISTORY

Phosphate Glass Run PG-6 was made on May 13 to May 15, 1968. An 8-inch diameter 304L stainless steel pot was filled with 62 liters of phosphate glass solids containing 2,400,000 curies of radioactivity. This produced a self-generating heat density of 158 watts/liter (9800 watts total in product based on analytical analysis) in the solids. Data pertaining to the PG-6 pot history is in Table $I$.

The run was considered to be successful and was uneventful. Foaming in the melter was mild and caused no appreciable problems. The normal melt overflow from the weir produced large drops that may have been from foam overflowing through the weir. The melter inadvertantly drained through the freeze valve twice during the run when the freeze valve temperature rose to about $620^{\circ} \mathrm{C}$. Both drains occurred before the pot was half filled and the valve was resealed both times before the melter was completely drained. At the conclusion of the run when it was time to drain the melter, a very high temperature (approximately 
TABLE 1. Phosphate Glass Run PG-6 Pot History

Prefill Measurements Obtained: Complete and within fabrication specifications:

Pot No. 39, 304 I stainless steel 8-inch diameter. Pot thermocouple wells were 310 stainless steel.

Dimensional Measurements, wall thickness scan: and 3-view photographs were obtained. weight; 254 lbs.

Run. Information:

\begin{tabular}{|c|c|}
\hline Run Date. & $5-13-68$ \\
\hline Feed Type. & $P W-1$ \\
\hline Denitrator Temperature, ${ }^{\circ} \mathrm{C}$ & 132 \\
\hline Melter Furnace Temperature, ${ }^{\circ} \mathrm{C}$ & 1220 \\
\hline Melt Average Temperature, ${ }^{\circ} \mathrm{C}$ & 1090 \\
\hline Total Curies in Feed. & $2,400,000$ \\
\hline $\begin{array}{l}\text { Total Heat in Pot (by feed. } \\
\text { analysis), } W \text {. }\end{array}$ & 9,600 \\
\hline Internal Heat Rate Density, w/litèr & 158 \\
\hline $\begin{array}{l}\text { Pot Wall Temperature During } \\
\text { Filling, }{ }^{\circ} \mathrm{C}\end{array}$ & 575 \\
\hline $\begin{array}{l}\text { Pot Centerline Temperature in Air } \\
\text { Cooled Furnace, }{ }^{\circ} \mathrm{C}\end{array}$ & 780 \\
\hline $\begin{array}{l}\text { Thermal Conductivity a avg } 580^{\circ} \mathrm{C}, \\
\mathrm{W} / \mathrm{m}^{2}\left({ }^{\circ} \mathrm{C} / \mathrm{m}\right)\end{array}$ & 1.1 \\
\hline $\begin{array}{l}\text { Volume Reduction (Feed. to solid, } \\
\text { based on feed at } 378 \mathrm{l} / \text { tonne) }\end{array}$ & 4.0 \\
\hline Expected Volume Reduction & 3.5 \\
\hline Volume of Glass Product, liters & 62 \\
\hline roduct density $\mathrm{kg} / \mathrm{liter}$ & 2.8 \\
\hline
\end{tabular}

Run Observations: Foaming in the melter was mild and caused no appreciable problems. The normal melt overflow from the weir produced large drops that may have been from foam overflowing through the weir.

The melter inadvertentiy arained through the freeze valve twice during the run when the freeze valve temperature rose to about $620^{\circ} \mathrm{C}$. Both, drains occurred before, the pot was half filled and the valve was resealed both times before the melter was completely 
drained. At the conclusion of the run when it was time to drain the melter; a very high temperature $\left(\sim 900^{\circ} \mathrm{C}\right)$ was required to thaw the freeze valve. The valve may have filled with calcined foam or feed that had not been converted to a melt.

Afterfill History in B-Cell:

Pot Lid Weld 8-15-68 $\begin{aligned} \text { Leak Check 9-10-69 } & -1.5 \times 10^{-7} \text { atm } \mathrm{cc} / \mathrm{sec} \text { (helium } \\ & \text { mass spectrometer) }\end{aligned}$

Kiethly (gamma 5-12-69

energy) scan

calorimetry

$$
\begin{aligned}
9-23-68- & 6.41 \mathrm{kw} \text { back calculated to } \\
& \text { fill date }=8.8 \mathrm{kw} \\
11-12-68- & 5.94 \mathrm{kw} \text { back calculated to } \\
& \text { fill date }=9.5 \mathrm{kw} \\
2-19-69- & 4.75 \mathrm{kw} \text { back calculated to } \\
& \text { fill date }=9.3 \mathrm{kw}
\end{aligned}
$$

Dimensional Measurements - 1-21-69

Air Temperature Profile - 5-12-69 - E temp $359^{\circ} \mathrm{C}$ maximum $346^{\circ} \mathrm{C}$ minimum

Water Temperature Profile - 9-30-68 - E temp $320^{\circ} \mathrm{C}$ maximum

$$
\begin{array}{ll}
11-15-68-G \text { temp } & 285^{\circ} \mathrm{C} \text { maximum } \\
& 240^{\circ} \mathrm{C} \text { minimum } \\
2-20-69-G \text { temp } 226^{\circ} \mathrm{C} \text { maximum } \\
200^{\circ} \mathrm{C} \text { minimum }
\end{array}
$$

Thermal Conductivity - 9-30-68-1.10 W/m $2\left({ }^{\circ} \mathrm{C} / \mathrm{m}\right)$ a avg temp of $181^{\circ} \mathrm{C}$

$$
\begin{aligned}
& \text { temp of } 181^{\circ} \mathrm{C} \\
11-15-68- & 1.07 \mathrm{~W} / \mathrm{m}^{2}\left({ }^{\circ} \mathrm{C} / \mathrm{m}\right) \text { e avg } \\
& \text { temp of } 148^{\circ} \mathrm{C} \\
2-20-69- & 1.04 \mathrm{~W} / \mathrm{m} 2\left({ }^{\circ} \mathrm{C} / \mathrm{m}\right) \text { a avg } \\
& \text { temp of } 125^{\circ} \mathrm{C} \\
5-12-69- & 0.996 \mathrm{~W} / \mathrm{m}^{2}\left({ }^{\circ} \mathrm{C} / \mathrm{m}\right) \text { a avg } \\
& \text { temp of } 282^{\circ} \mathrm{C}
\end{aligned}
$$

Pressure Measurements* - No Pressurization.

Storage Conditions - Pot was stored primarily in water during 17 months in B-Cell.

\section{Afterfill History in A-Cell:}

Assembled in water environmental storage test pod No. 7 in A-21-1 cubicle - 10-1-69.

Pot-Pod Leak check (final) - 9-30-69-8.3 $10^{-8} \mathrm{~atm} \mathrm{cc/sec}$ 
Afterfill History in A-Cell (contd)

Test Environment - Water a. $\sim 90^{\circ} \mathrm{C}$.!

Thermal Conductivity - 10-16-69-1.18 W/m $\left({ }^{\circ} \mathrm{C} / \mathrm{m}\right)$ (a. $137^{\circ} \mathrm{C}$ avg temp

$$
\begin{aligned}
11-20-69- & 1.21 \mathrm{~W} / \mathrm{m}^{2}\left({ }^{\circ} \mathrm{C} / \mathrm{m}\right) \\
& \\
1-15-70- & 137^{\circ} \mathrm{C} \text { avg temp } \\
& 1.18 \mathrm{~W} / \mathrm{m}^{2}\left({ }^{\circ} \mathrm{C} / \mathrm{m}\right) \\
& \text { a } 129^{\circ} \mathrm{C} \text { avg temp }
\end{aligned}
$$

Pressure Measurements - Continuous, no pressurization.

General Tést Conditions:-

Electric Auxiliary Heat Used.

Normal Water Level 84 in (about 9 in below the pot thermocouple well openings). Thermocouple Connections Air cooled. Pod air sweep with T/C cooling air: maintained. Upper pod cooling coil, used as a condenser.

General observations: No unusual behavior of pot or pot: contents was, observed until core drills of 1-15-71 revealed liquid in the pot and material "oozed" out of the core drill holes.

The pod water level was filled to above the thermocouple well openings on $10-28-69$ and the level remained excessive until $10-31-69$.

* Pressure measurements in B-Cell are made with a Bourdon pressure tube gage mounted on the pot flange by a jumper. Pressure readings are made by visual observations when the pots. are moved in the cell. 
$\left.900^{\circ} \mathrm{C}\right)$ was required to thaw the freeze valve. The valve may have filled with foam or feed when it was resealed earlier in the run. The melter operation does not appear to be a significant factor in the difficulty encountered with the PG-6 pot in environmental storage.

During the filling of the waste receiver the wall temperature was maintained at $575{ }^{\circ} \mathrm{C}$ to promote slumping of the glass in the pot to assure uniform filling. The maximum centerline temperature encountered during the run was approximately $900{ }^{\circ} \mathrm{C}$ and the steady state pot centerline temperature was $780^{\circ} \mathrm{C}$ with a $400^{\circ} \mathrm{C}$ wall temperature with the pot setting in the furnace with cooling air on.

After the run was completed the pot was placed in water storage in B-Cell where it remained except for short time periods when it was transferred for welding, measurements, and air temperature profiles. The temperature history of the pot is presented in Figure 1. From this it is seen that since the run in May 1968 the pot centerline temperature has been below approximately $400^{\circ} \mathrm{C}$ and the average temperature was approximately $200^{\circ} \mathrm{C}$. During the time the pot was in an environmental test pod (where the thermowell is known to have failed) the centerline temperature decreased from 190 to $125^{\circ} \mathrm{C}$.

A Iid was welded on the pot on August 15, 1968, about 3 months after the run. The first leak check of the pot was made on september 10, 1969, and the helium leak rate of $1.5 \times 10^{-7}$ atm cc/sec demonstrated that there were no leaks in the pot and that no fluid. was present or off gassing would have made the leak test unsuccessful. 


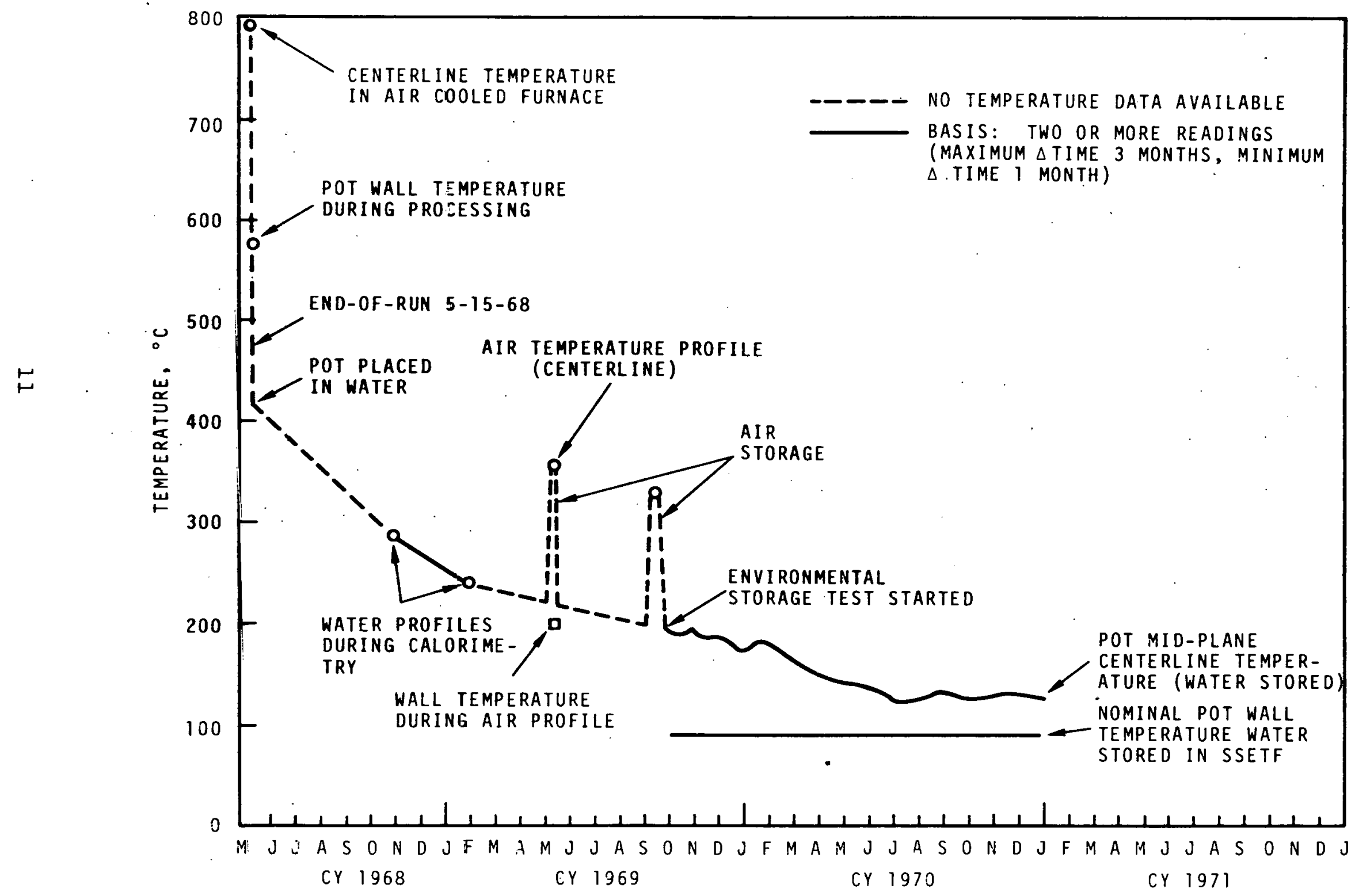

FIGURE 1. PG-6 Pot Temperature History 
During the seventeen months the pot was stored in B-Cell other post run measurements were taken. These included a gamma energy scan, calorimetry tests, dimensional measurements, and temperature profiles. The Bourdon tube pressure gage mounted on the pot flange did not indicate any pressurization during this time.

The pot was transferred to $\mathrm{A}-\mathrm{Cell}$ where it was placed in a water environmental storage pod on October 1, 1969. Before the environmental test started (September 30, 1969) the pot and pot to pod piping was leak tested and the $8.3 \times 10^{-8} \mathrm{~atm} \mathrm{cc/sec}$ leak test result again indicated that no volatile material was in the pot and that there were no leaks.

During environmental storage the pot fission product heat was supplemented by a pod heater to maintain the storage water at approximately $90^{\circ} \mathrm{C}$. The upper pod cooling coil served as a condenser to prevent excessive water loss. Makeup water was added to the pod daily to replace some evaporation losses to the pod vent and on one known occasion the water level was accidentally increased above the pot thermowell openings. The normal water level was about 9 inches below the thermowell openings.

Measurements of the pot temperature and pressure during the environmental storage did not indicate any unusual behavior within the pot.

'the pot was removed from the environmental pod and was core drilled on January 15, 1971. The core drill taken in zone 1, 19 inches from the top of the pot, revealed a semi-fluid 
region within the center of the pot and some of the fluid ran down the side of the pot where it solidified. A second core drill 51 inches from the top of the pot revealed only a slight amount of fluid present. These two core drill holes are shown in Figure 2 and a closeup of the upper hole is shown in Figure 3 .

A total of three core drill samples were obtained from the pot from zones 1 (top), 3 , and 6 (bottom) for the standard C-Cell tests (leach rate, dispersibility, and gamma energy analysis [GEA]). The samples in zones 1 and 3 were moist and froze in the core drill bits upon cooling. Special equipment was developed to remove the samples. The core section. nearest the pot wall in zones 1 and 3 (about 1.5 inches long) appeared to be typical devitrified phosphate solid. The remainder of the core in zone 1 was crystalline, wet, and tacky in places. The zone 6 sample was chalky and more crumbly than normal and although the material was dry $(<0.1$ wto water $)$ it behaved like it had been wet at some previous time.

In addition to the core samples, samples were taken of the fluid material in the pot in zone 126 inches from the top of the pot (it rapidly solidified when the temperature decreased from the $100^{\circ} \mathrm{C}$ pot centerline temperature to a cell ambient temperature of about $40^{\circ} \mathrm{C}$ ). Samples were also taken from the colidified illaterlal that had oozed down the pot wall and from the crumbs in the zone 3 hole 51 inches from the top of the pot. Analysis of these samples showed them to contain about 15 wt\% water (except the zone 3 hole was $4 \mathrm{wt} \%$ ) and to be very soluble in water. Results from the analysis of these samples are discussed in the next section. 


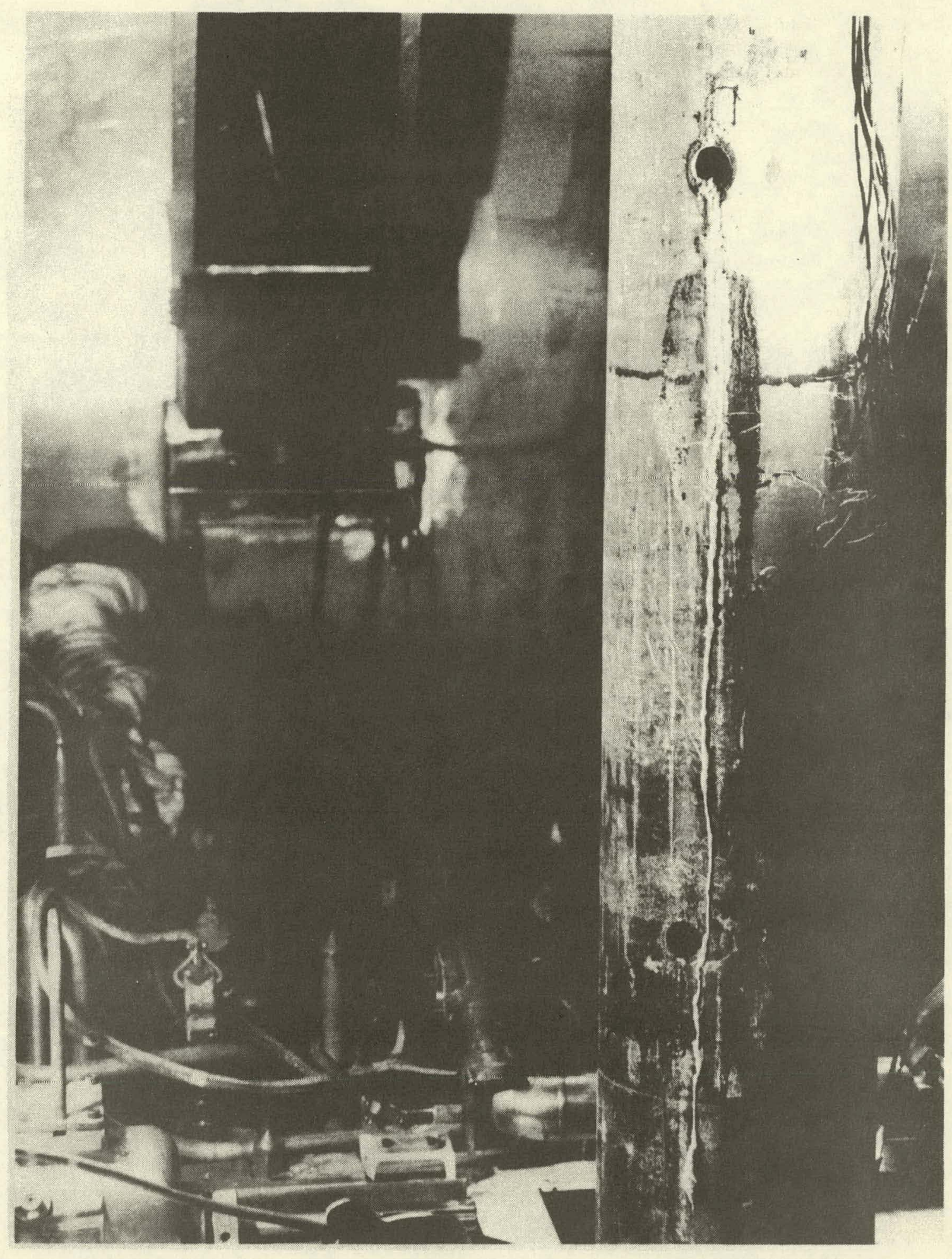

Neg 710217-6

FIGURE 2. Upper and Middle Core Drill Holes on PG-6 Pot 


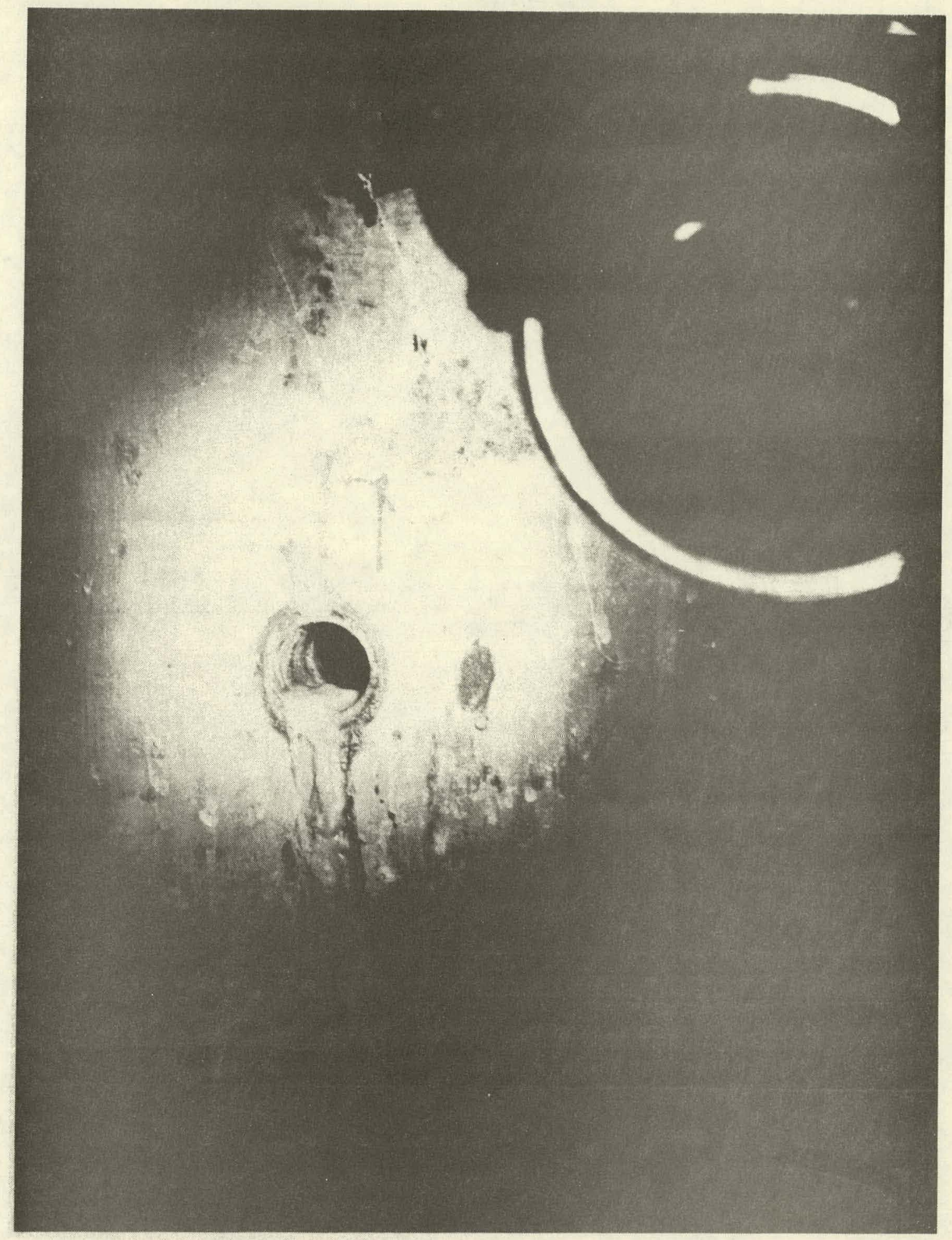

Neg 710217-12

FIGURE 3. Upper Core Drill Hole on PG-6 Pot 
Inspection of the top surface of the pot revealed it to be crumbly and cracked like a dried-up bed of clay. A rod was pushed down 8 inches into the surface, indicating that the product had deteriorated to at least this depth.

\section{SIGNIFICANT FINDINGS}

Water entered the PG- 6 pot through the failed pot thermocouple wells while it was in the water environmental test pod. It was determined that the thermowells were failed by not being able to pull a substantial vacuum on either of the thermowells and by pressurizing the pot by applying air to the end of the thermowells. The intermediate thermowell (located halfway between the pot centerline and the pot wall) indicated a more substantial leak than the centerline thermowell. (As discussed before, the thermowells were sound at the start of the environmental test.)

As a result of the failed thermowells, it was possible for water in the environmental pod to enter the pot and attack the product. The water level was nominally nine inches below the thermowell opening but it was overfilled to above the openings on one known occasion. Water could also enter the pot from condensation that occurs in the upper region of the environmental pod. The pod water was maintained at 75 to $95{ }^{\circ} \mathrm{C}$ and vapors were condensed by the upper pod cooling coil and the top pod flange. The condensed moisture could drip on the thermowell opening and enter the pot. This situation is depicted schematically in Figure 4.

A review of the existing corrosion data (Table II) shows that corrosion of $304 \mathrm{~L}$ stainless steel at temperatures of 


\section{PHOSPHATE GLASS STORAGE DG-6 IN ENVIRONMENTAL POD}

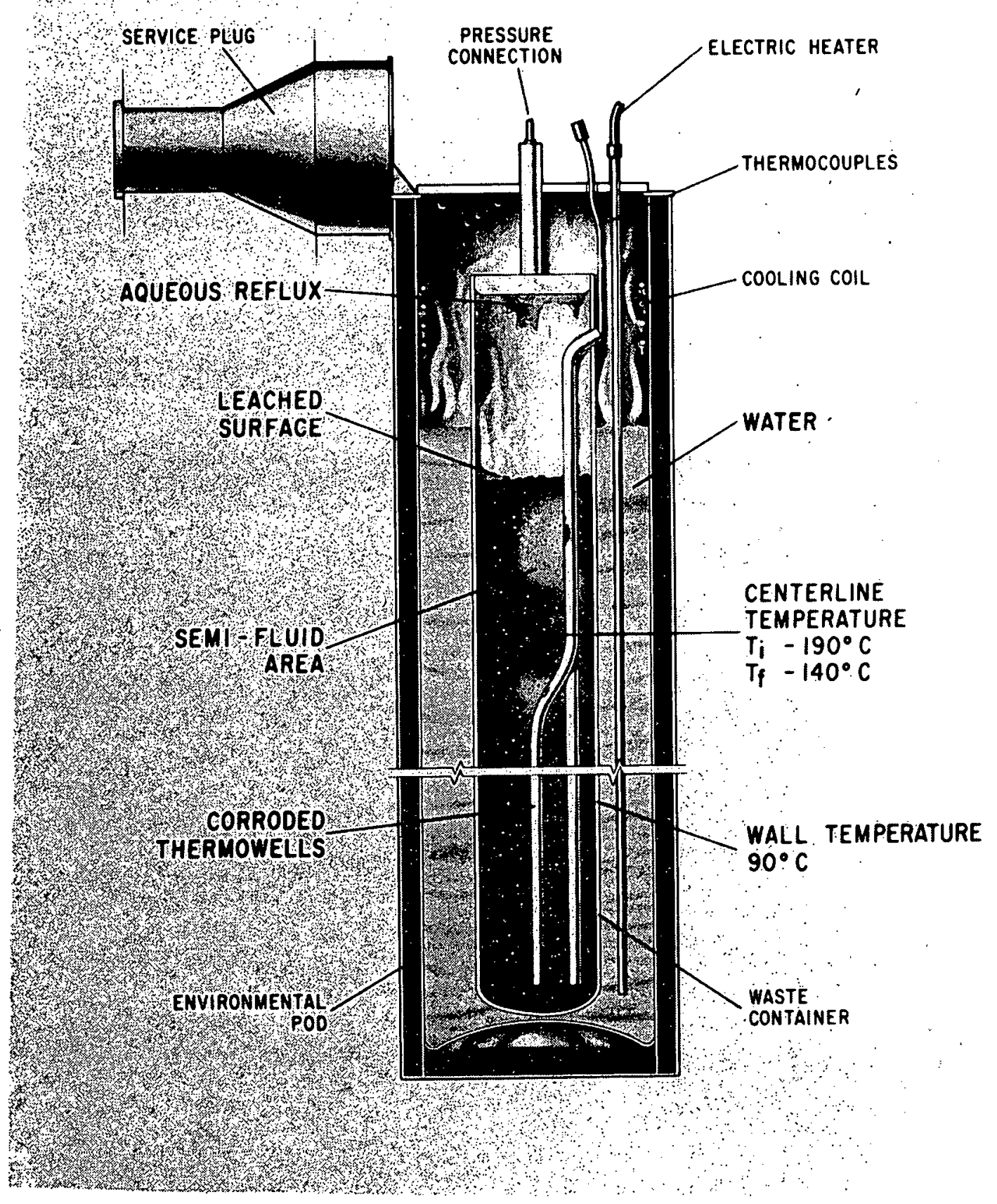

Neg

711566-1

FIGURE 4. PG-6 Pot In Environmental storage 
TABLE II. Corrosion Rates of Storage Vessels

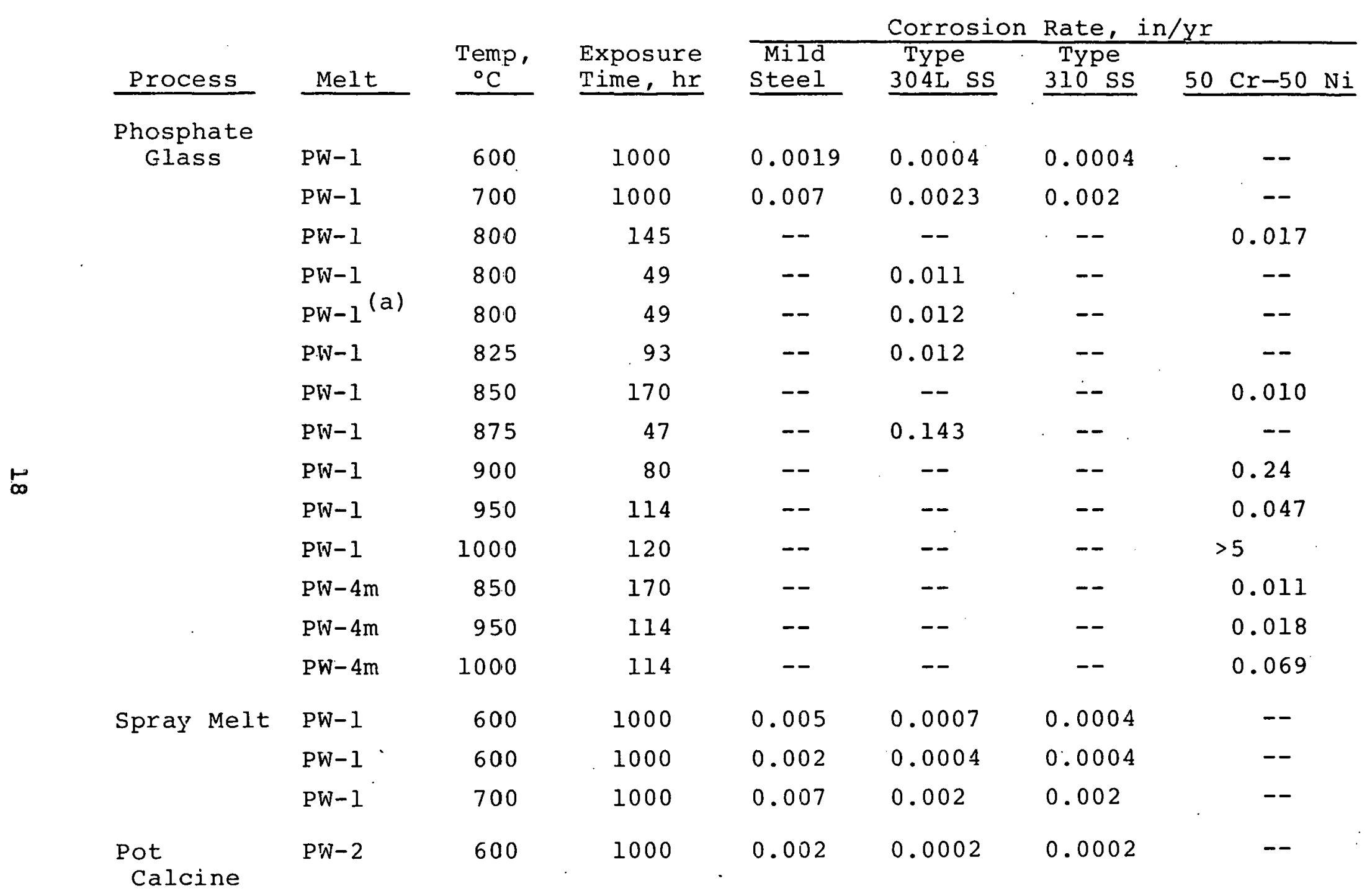

(a) $0.03 \mathrm{M}$ fluoride in $\mathrm{PW}-1$ waste solution. 
$825^{\circ} \mathrm{C}$ or less in phosphate glass melts is less than 0.012 inches/yr. Although the PG- 6 pot thermowells are made of 310 stainless steel, it is recognized that for this type of service the 310 is a better material. The thermowells are made of $1 / 2$ and $3 / 4$ inch sch 80 pipe (about 0.15 -inch wall thickness). An estimated corrosion rate for the thermowells, averaged over the entire life from pot filling to core drilling, is 0.06 inches/yr. Based on the pot temperature history, (below about $400^{\circ} \mathrm{C}$ as discussed previously and shown in Figure 1 ) and the corrosion data in Table II the thermowells should not have failed.

During laboratory tests it has been observed that a sticky substance is found on the surface of devitrified phosphate glass. (3) Whether it is exuded from the glass or is from adsorbing moisture from the air is not known. Analysis of the sticky material shows it to have the same composition as the devitrified solid but it is also definitely acid (i.e., probably phosphoric acid):. This substance could cause corrosive problems in the temperature range encountered.

A possible corrosion mechanism could be caused by activation of the stainless steel if an excessive temperature occurred during filling that exceeded the activation temperature of the metal and allowed corrosion to start. For corrosion to continue the metal would have to somehow fail to deactivate during and following cooldown. The maximum temperature that

(3) R. J. Thompson, J. E. Mendel, J. H. Kleinpeter, Waste Solidification Demonstration Program: Characterization of Nonradioactive Samples of Solidified High-Level Waste, pp. 4.2, BNWL-1393, June 1970. 
occurred in the PG-6 pot is estimated at $900^{\circ} \mathrm{C}$ in the lower half of the pot and should have occurred early in the run during one of the melt batch dumps. During. Phosphate Glass Run PG-7, the maximum centerline temperature at any time during the run was $875^{\circ} \mathrm{C}$ and a thermowell failed in this pot within 10 months.

The corriosion data in Table II indicate that activation may occur at about $87.5^{\circ} \mathrm{C}$ as the corrosion rate is a factor of 10 higher than at $825^{\circ} \mathrm{C}$. This mechanism does not seem too probable at lower temperatures as the solid waste is a poor electrical conductor and current flow is required for activation type corrosion. Also, the temperature at final failure was quite low for this type corrosion and if the waste were a solid it should have served as a protective coating for the stainless steel.

A scan was made of the pot wall thickness using an ultrasonic type device. Measurements were taken from 12 inches above the product to the bottom of the pot at intervals of 4 to 6 inches and in 10 locations around the pot at each level measured. The measurements were fairly uniform and varied from 0.313 to 0.352 inches and indicate no pot wall corrosion occurred. (The standard wall thickness for 8-inch sch 40 pipe is 0.322 inches.)

Samples of the PG-6 pot solidified waste were obtained as discussed earlier. The results of the analysis of these samples are given in Table III. These data show that the semi-fluid material had a water content of about 15 wto, that it was very soluble in water, and that it was acidic. 
TARLE III. Laboratory Analysis of PG-6 Core Hole and Core Drill Samples

\begin{tabular}{|c|c|c|c|c|c|c|c|c|c|c|}
\hline \multirow[b]{2}{*}{ Sample Number and Location } & \multicolumn{4}{|c|}{$\begin{array}{c}\text { Gamma Energy Analysis, } \\
\text { Counts/min - } g(a)\end{array}$} & \multirow{2}{*}{$\begin{array}{c}\text { Water } \\
\text { Content, (b) } \\
\text { wto } \\
\end{array}$} & \multirow{2}{*}{$\begin{array}{c}\text { Solubility } \\
\text { on } \\
\text { Dry Basis, } \\
\text { wtg } \\
\end{array}$} & \multirow{2}{*}{$\begin{array}{l}\text { Na Content } \\
\text { on } \\
\text { Dry Basis, } \\
\text { wtg } \\
\end{array}$} & \multirow{2}{*}{$\begin{array}{l}\text { P Content } \\
\text { on } \\
\text { Dry Basis, } \\
\text { wt } 8 \\
\end{array}$} & \multirow{2}{*}{$\begin{array}{l}\mathrm{Na} / \mathrm{P}^{(\mathrm{e})} \\
\mathrm{Ratio} \\
\end{array}$} & \multirow[b]{2}{*}{$\mathrm{PH}^{\circ}$} \\
\hline & ${ }^{134} \mathrm{Cs}$ & ${ }^{137} \mathrm{Cs}$ & ${ }^{144} \mathrm{Ce}$ & ${ }^{106} \mathrm{Ru}$ & & & & & & \\
\hline $\begin{array}{l}\text { W-1095, Semi-fluid from } \\
\text { Top Hole No. } 29\end{array}$ & 8 & $20:$ & 14 & 6 & 15 & 89 & 11.1 & 33 & 0.34 & $3^{(f)}$ \\
\hline $\begin{array}{l}\text { A-1098, Solid Scrapings } \\
\text { from Top Hole No. } 29\end{array}$ & 12 & 354 & 41 & 20 & 15 & 75 & 10.6 & 25 & $0.4 \dot{2}$ & \\
\hline $\begin{array}{l}\text { W-1097, Solid Scraping } \\
\text { from Side of pot. }\end{array}$ & 11. & 266 & $28^{(d)}$ & 9 & 11 & 73 & 10.5 & 24 & 0.44 & \\
\hline $\begin{array}{l}\text { W-1096, Solid Tear Scraping } \\
\text { from Side of Pot. }\end{array}$ & 17 & 400 & 32 & 19 & 13 & 92 & 11.9 & 30 & 0.40 & \\
\hline $\begin{array}{l}\text { W-1099, Sólids from Middle } \\
\text { Hole No. } 30\end{array}$ & 22 & 542 & 685 & 23 & 4 & 17 & 5.7 & 16 & 0.36 & \\
\hline Core Drill Samples & & & & & . & & & & & \\
\hline $\begin{array}{l}\text { 29-A (Top Core - } 26 \text { in from } \\
\text { top of pot) }\end{array}$ & & 31 & 167 & & & & & & & \\
\hline $\begin{array}{l}\text { 29-B (Top Core - } 26 \text { in from } \\
\text { top of pot) }\end{array}$ & & 35 & 168 & & & & & & & \\
\hline $\begin{array}{l}\text { 29-C (Top Core }-26 \text { in from } \\
\text { top of pot) }\end{array}$ & & 32 & 171 & & & 、 & & & & \\
\hline $\begin{array}{l}\text { 30-A (Middle Cone - } 51 \text { in } \\
\text { from top of pot) }\end{array}$ & & 3.2 & 196 & & & & & & & \\
\hline $\begin{array}{l}\text { 30-B (Middle Core }-51 \text { in } \\
\text { from top of pot) }\end{array}$ & & 3.2 & 196 & & & & & & & \\
\hline $\begin{array}{l}\text { 32-C (Bottom Core - } 89 \text { in } \\
\text { from top of pot) }\end{array}$ & & 32 & 154 & & & & & & & \\
\hline $\begin{array}{l}\text { 32-D (Bottom Core - } 89 \text { in } \\
\text { from top of pot) }\end{array}$ & & 32 & 258 & & & . & & & & \\
\hline $\begin{array}{l}32 \text { (Bottom Core }-89 \text { in } \\
\text { from top of pot) Random } \\
\text { Pieces }\end{array}$ & & & & & $<0.1$ & . & & & & \\
\hline
\end{tabular}

(a) Precision of \pm 48 on core samples and \pm 208 on others.

(b) Based on weight loss on heating to slightly over $100^{\circ} \mathrm{C}$.

(c) Based on approximately one gram dry solid placed in $10 \mathrm{ml}$ of water.

(d) Average of 2 counts.

(e) Feed Na/P $=0.3(59.75 \mathrm{~g} / \mathrm{l} \mathrm{Na} / 198.80 \mathrm{~g} / \mathrm{l} \mathrm{P}$ )

(f) 2 gram samp:e in $10 \mathrm{ml}$ of water. 
The data indicate that the water probably entered the pot in the vicinity of the upper portion of the solidified waste as shown in Figure 4. Based on an average water content of 10 wto and assuming water to be in a 4 inch diameter by 3 foot high cylindrical section in the top of the pot, the amount of water present was about 2 liters.

The $\mathrm{Na} / \mathrm{P}$ ratio in the semi-fluid material was slightly higher than that theoretically in the solid. The normal sequence of water attacks on phosphate solids is to leach out low-valent cations leaving a skeleton of high-valent phosphate material. It appears that the leaching continued until the skeleton became, weakened and a considerable volume of it collapsed. The collapsed skeleton should contain most of the rare earths and remain relatively insoluble.* Because the leaching advanced so far only about 23\% of the phosphate remained tied up with the skeletal remnants. (This was calculated assuming a $\mathrm{Na} / \mathrm{P}$ ratio of 0.39 in the dissolved material and assuming that all sodium was dissolved.)

The liquid rising to the top of the dissolved material would be expected to have the highest $\mathrm{Cs} / \mathrm{Ce}$ ratio because the cerium phosphate residue, being of larqe molecular weiqht, will tend to settle. The liquid rising to the top should also

*It is known that the ${ }^{144} \mathrm{Ce}$ leach rate is usually about $10^{-7}$ $\mathrm{g} / \mathrm{cm}^{2} /$ day and relatively independent of the $13 \mathrm{Cs}$ leach rate, thus the cerium leach rate is often a factor of 100 lower than that of cesium. A factor of about 70 is required to explain the analytical results in Table III. 
be least viscous, i.e., contain the most water. Therefore, the liquid first out of the hole (the tear) and the sample from the hole (which is in effect a supernate sample of the remaining material) would be expected to have the highest $\mathrm{Cs} / \mathrm{Ce}$ ratio, which they do.

The material which drained from the top hole was more concentrated than the material remaining inside. More rapid evaporation based on the higher surface to volume ratio explains this. The solids material from the middle hole had a much lower $\mathrm{Cs} / \mathrm{Ce}$ ratio, nearer to that of the solid. Less water reached this point in the pot, thus leaching had not advanced very far.

The gamma energy analysis of the core drill samples indicates a nearly uniform distribution of fission products from the top to the bottom of the pot. The slight increase in $144 \mathrm{Ce}$ in the middle (mid-plane) core is not thought to be significant. The core samples are of the solid product within $11 / 2$ inches of the pot wall.

Accelerated leach rate data with 45 to 60 mesh solid samples of devitrified $\mathrm{PW}-1$ phosphate glass product indicate that as high as 20 to 50 wto of the product is leached away during three days in boiling water. (4) From this it is not too surprising to find the fluid material in the pot since there was probably boiling and refluxing occurring within

(4) R. J.Thompson, J.E. Mendel, J.H. Kleinpeter, Waste Solidification Demonstration Program: Characterization of Nonradioactive Samples of Solidified High-Level Waste, pp. 6.2, Table 6.1, BNWL-1393, June 1970. 
the pot. Additional efforts to duplicate the reaction of water with the product of PG-6 were carried out in the laboratory using nonradioactive phosphate glasses prepared from PW-1 type waste. Both good quality glass and devitrified glass were tested in order to evaluate the effect of devitrifiation which occurs on storage at elevated temperatures.

Two large specimens of the devitrified solid were placed in a flask fitted with a reflux condenser. One $(45.5 \mathrm{gm}$ rectangular piece) was immersed in the water and the other (19.8 $\mathrm{gm}$ rectangular piece) was suspended in the vapor phase. The flask as heated to the boiling point of the water and maintained at that temperature for 33 days. A specimen of the vitreous solid ( $9 !: 5 \mathrm{gm}$ rectangular piece) was immersed in boiling water in a second flask for 32 days. Visual observations were made periodically, and at the end of the test period the specimens were removed, dried at $200^{\circ} \mathrm{C}$, weighed and sectioned.

The devitrified specimen immersed in boiling water began reacting almost immediately. After 90 minutes the initially dark grey color had changed to light tan. One day later the specimen had deteriorated markedly and the aqueous phase had become saturated with soluble salts: Recrystallization of thece calta was cvident, and at the end of the teat it was difficult to distinguish the original specimen from the material which had dissolved and reprecipitated. After drying the mass for 16 hours at $200^{\circ} \mathrm{C}$ the surface was coated with a sticky substance which was exuding from the solid. The weight loss measurement was meaningless because of the recrystallization. A cross-section of the mass revealed that the reaction had completely penetrated the specimen and that the solid was visually homogeneous. 
The devitrified specimen suspended in the vapor phase reacted somewhat more slowly than that in the liquid phase. Six days elapsed before the sample color completely faded, and at the end of the test the sample was still intact; however, the specimen lost 48 percent of its original weight during the 33 day test. The cross-section again showed that the reaction had completely penetrated the sample.

The vitreous sample immersed in boiling water gave evidence of only slight reaction. A thin layer of salt covered the sample surface by the end of the second day, but otherwise no visual evidence of reaction was noted. The weight loss was 16.5 percent over the 32 day period for the $9.5 \mathrm{gm}$ sample. (Compares with 20 to $50 \mathrm{wt} \%$ loss in three days for 45 to 60 mesh devitrified samples.)

The behavior of the devitrified specimens resulted in reaction products very similar to those observed in the PG-6 pot. This substantiated the conclusion that the product had undergone severe leaching by the water that penetrated the pot.

An attempt was made to determine the amount of radioactivity that entered the pod water from the pot (the water was transferred: out before the pot was core drilled). Radiation readings of the external cell piping through which the pod water was transferred out indicated that an excessive amount of radioactivity did not pass through the lines as the readings were near normal. 'Since the pot thermowell openings were normally above the surface of the pod storage water, the main mechanism for activity transfer from the pot to storage water would have been by distillation. 
A summary was made of the leak testing of the phosphate glass pots. (Table IV.) As mentioned previously the PG-7 pot was known to have developed a leaky thermowell during a 10 month time span between leak checks. The summary shows that PG-1, PG-2, and PG-3 were leak checked within a month after filling and have not been rechecked. These pots did not contain much fission product heat, however, and may not be a problem (lower temperatures and possibly the product has not oozed liquid if it has not devitrified). Pot PG-5 has not been checked and is a good cándidate for checking. The PG-5 pot had nearly $9 \mathrm{kw}$ in it at filling, but was a l2-inch diameter pot and as such the centerline temperature during air storage was only $650^{\circ} \mathrm{C}$. 
TABLE IV. Leak Check Summary of all Phosphate Glass Pots.

\begin{tabular}{|c|c|c|c|c|}
\hline Run No. & $\begin{array}{c}\text { End of of Run } \\
\text { Date }\end{array}$ & $\begin{array}{l}\text { Leak Check } \\
\text { Date. } \\
\end{array}$ & $\begin{array}{c}\text { Leak Rate } \\
\text { (atm cc/sec) } \\
\end{array}$ & $\begin{array}{c}\Delta \text { Months } \\
\text { from Run } \\
\text { to } \\
\text { Leak Check } \\
\end{array}$ \\
\hline PG-1 & $11-22-67$ & $12-19-67$ & $1.13 \times 10^{-8}$ & 1 \\
\hline PG-2 & $12-14-67$ & $1-3-68$ & $2.35 \times 10^{-8}$ & 0.7 \\
\hline$P G-3$. & $1-27-68$ & $2-5-68$ & $4.6 \times 10^{-8}$ & 0.2 \\
\hline$P G-4$ * & $3-2-68$ & Not checked & --- & Not checked \\
\hline$P G-5 * *$ & $4-25-68$ & Not checked & -- & Not checked \\
\hline \multirow[t]{4}{*}{$P G-6$} & \multirow[t]{4}{*}{$5-15-68$} & $9-10-69$ & $1.5 \times 10^{-7}$ & 16 \\
\hline & & $9-16-69$ & $8.0 \times 10^{-8}$ & 16 \\
\hline & & $9-30-69$ & $8.3 \times 10^{-8}$ & 16 \\
\hline & & $2-10-71$ & Failed TC Well & 33 \\
\hline \multirow[t]{2}{*}{$P G-7 * * *$} & \multirow[t]{2}{*}{$7-10-69$} & $7-23-69$ & $4.1 \times .10^{-7}$ & 0.4 \\
\hline & & $5-14-70$ & Failed TC Well & 10 \\
\hline \multirow[t]{3}{*}{$P G-8$} & \multirow[t]{3}{*}{$8-13-69$} & $8-26-69$ & $5.4 \times 10^{-8}$ & 0.5 \\
\hline & & $6-18-70$ & $2.0 \times 10^{-7}$ & 10 \\
\hline & & $6-19-70$ & $8.8 \times 10^{-7}$ & 10 \\
\hline P.G-9 & $9-22-69$ & $3-23-70$ & $2.6 \times 10^{-7}$ & 6 \\
\hline$P G-10$ & $9-29-69$ & $6-4-70$ & $7.0 \times 10^{-7}$ & 9 \\
\hline PG-11 & $12-2-69$ & $2-10-70$ & $1.7 \times 10^{-8}$ & 2.3 \\
\hline
\end{tabular}

\footnotetext{
* PG-4 pot lid weld is defective.

* Lid welded in place but leak check not completed.

*** Unable to leak check PG-7 in A-Cell (5-14-70) because of $a$, leaking thermocouple well but pot was placed in air environmental test.
} 


\section{DISTRIBUTION}

No. of

Copies

OFFSITE

1 .

AEC Chicago Patent Group

G. H. Lee

2.

AEC Division of Technical Information Extension

3

AEC Division of Reactor Development and.

Technology

W. H. Regan,

2.

Union Carbide Corp. (ORNL)

R. E. Blanco

J. O. Blomeke

ONSITE

1

AEC, RDT Site Representative

A. D. Toth

5

WADCO

J. M. Atwood

A. G. Blasewitz

17

Battelle-Northwest

R. E. Burns

J. I. McElroy

J. E. Mendel

K. J. Schneider.

F. P. Roberts

R. F. Maness

Technical Information

Technical Pubication 